\title{
TEORI MOTIVASI ABRAHAM H. MASLOW DAN IMPLIKASINYA DALAM KEGIATAN BELAJAR MATEMATIKA
}

\author{
Try Gunawan Zebua ${ }^{1 *}$ \\ ${ }^{1}$ IKIP Gunungsitoli, Gunungsitoli, Indonesia \\ *trygunawan@rocketmail.com
}

Diterima: 09 Juni 2021. Disetujui: 15 Juli 2021. Dipublikasikan: 31 Juli 2021

\begin{abstract}
ABSTRAK
Salah satu Teori Motivasi yang terkenal adalah Teori Motivasi Abraham H. Maslow yang juga disebut sebagai Teori Motivasi Abraham H. Maslow atau Teori Hierarki Kebutuhan Maslow. Hasil Belajar Matematika siswa bisa dikategorikan rendah, sehingga perlu diberikan solusi dengan mengimplikasikan Teori Motivasi Abraham H. Maslow. Metode penelitian yang digunakan dalam penelitian ini adalah Studi Literatur, dimana peneliti menganalisis Teori Motivasi Abraham H. Maslow langsung dari buku Tulisan Abraham H. Maslow yang berjudul Motivation and Personality (terjemahan Achmad Fawaid dan Maufur, penerbit Cantrik Pustaka), kemudian peneliti menganalisis dampak Teori tersebut jika diimplikasikan dalam kegiatan belajar matematika. Teori Motivasi Abraham H. Maslow pada tahap pertama dapat diterapkan dalam kegiatan belajar matematika dengan cara memberikan makanan dan minuman kepada siswa, tahap kedua dapat diterapkan dengan cara membuat siswa aman dalam kegiatan belajar matematika, tahap ketiga dapat diterapkan dengan menjalin komunikasi antara guru dan siswa, tahap keempat dapat diterapkan dengan cara adanya saling menghargai antara guru dengan siswa maupun sesama siswa, dan tahap kelima dapat diterapkan dengan cara memberikan kesempatan kepada siswa untuk mengemukakan pendapat dalam kegiatan diskusi. Penerapan Teori Motivasi Abraham H. Maslow dapat mempengaruhi atau meningkatkan Hasil Belajar Matematika siswa. Siswa akan menjadi fokus atau konsentrasi saat belajar matematika di dalam kelas.

Kata kunci: Teori Motivasi Abraham H. Maslow, Implikasi, Belajar Matematika
\end{abstract}

\begin{abstract}
One of the well-known Motivation Theory is Abraham H. Maslow's Motivation Theory which is also known as Abraham H. Maslow's Motivation Theory or Maslow's Hierarchy of Needs Theory. Students' Mathematics Learning Outcomes can be categorized as low, so a solution needs to be given by implication Abraham H. Maslow's Motivation Theory. The research method used in this research is Literature Study, where the researcher analyzes Abraham H. Maslow's Motivation Theory directly from Abraham H. Maslow's book entitled Motivation and Personality (translated by Achmad Fawaid and Maufur, publishers of Cantrik Pustaka), then the researcher analyzes the impact of the theory. if it is implied in mathematics learning activities. Abraham H. Maslow's Motivation Theory in the first stage can be applied in learning mathematics activities by providing food and drinks to students, the second stage can be applied by making students safe in learning mathematics activities, the third stage can be applied by establishing communication between teachers and students, the fourth stage can be applied by means of mutual respect between teachers and students and fellow students, and the fifth stage can be applied by providing opportunities for students to express opinions in discussion activities. The application of Abraham H. Maslow's Theory of Motivation can influence or improve students' Mathematics Learning Outcomes. Students will be the focus or concentration when learning mathematics in the classroom.
\end{abstract}

Keywords: Abraham H's Motivation Theory, Maslow, Dream, Learning Mathematics. 


\section{Range: Jurnal Pendidikan Matematika Vol. 3 No. 1 Tahun 2021 Try Gunawan Zebua}

\section{Pendahuluan}

Matematika itu ada dimana saja dan kapan saja. Hal tersebut dinyatakan oleh Marsigit, dimana Marsigit (2013:3) mengatakan bahwa: kita semua telah menyaksikan, bahwa dewasa ini tiadalah aspek kehidupan kita yang terbebas dari unsur dan peran matematika, mulai dari transaksi jual beli di warungwarung kecil hingga sampai teknologi komputer, informatika dan ruang angkasa. Matematika itu ada dimana saja, dimana matematika itu dapat kita temukan saat kita berada di sekolah, di pasar, di rumah, di kampus maupun di kantor dan di rumah sakit, bahkan di tempat-tempat lainnya (dimana saja).

Matematika dapat kita temukan saat di sekolah dan di kampus karena di sekolah dan di kampus ada mata pelajaran atau mata kuliah matematika, atau berbagai nama lain selain matematika tetapi pada intinya adalah matematika atau bagian dari matematika dan terkait dengan matematika. Hal tersebut karena matematika itu dasar dari ilmu pengetahuan lain atau berkaitan dengan ilmu pengetahuan lain. Selain itu, sebelum kita masuk atau terdaftar disuatu sekolah atau kampus tertentu, terkadang ada salah satu tes matematika yang digunakan, sehingga membuat matematika itu sangat berguna atau penting sekali untuk kita semua.

Matematika dapat kita temukan di pasar, di rumah, di kantor, di rumah sakit, dan bahkan di berbagai tempat lain karena saat di pasar, di rumah, di kantor, di rumah sakit, dan bahkan di berbagai tempat lain tersebut kita dapat melihat atau mendengarkan disebutkan angka-angka atau bilangan (1,2,3, Rp. 1.000,00, Rp. 3.000,00, dan lain-lain sebagainya), bahkan kita mendengarkan atau melihat dilakukan operasi Penjumlahan (+), Pengurangan (-), Perkalian $(\times)$ dan bahkan Pembagian $(\div)$. Itu disebabkan karena angka-angka atau bilangan dan operasi tersebut disebut sebagai matematika. Hal tersebut dinyatakan oleh Kamus Besar Bahasa Indonesia (KBBI), dimana Kamus Besar Bahasa Indonesia (KBBI) mengatakan bahwa: matematika ilmu tentang bilangan, hubungan antara bilangan dan prosedur operasional yang digunakan dalam penyelesaian masalah mengenai bilangan.

Misalnya di pasar, seorang pembeli ingin membeli Apel. Pembeli yang membeli apel tersebut kemudian bertanya kepada si penjual, berapa harga apel itu? Jawab si penjual: "Harganya Rp. 30.000,00/Kg”. Rp. 30.000,00 itu adalah matematika. Begitu juga saat di rumah sakit, seorang dokter bertanya kepada para perawat disekitarnya, jam berapa sekarang? Jawab para perawat: "Jam 14.00 wib pak dokter". "14" itu adalah matematika, dan lain-lain sebagainya di tempat lain, sehingga kita tidak dapat menghindari atau menjauhi matematika, serta matematika tersebut sangat kita perlukan karena dapat menjelaskan berapa berat suatu barang, waktu, harga barang, dan lain-lain sebagainya. Matematika itu ada kapan saja karena matematika ada atau dipelajari sejak zaman dulu di Mesir, Babilonia, dan bahkan hingga saat ini di Bangsa kita Indonesia

Matematika itu dalam kegiatan belajar atau saat belajar disebut sebagai belajar matematika. Selain saat belajar matematika, belajar matematika juga dapat dilakukan sebelum belajar matematika dan sesudah belajar matematika. Dilakukan sebelum belajar matematika saat seorang siswa mengerjakan tugas yang akan diserahkan saat belajar matematika, saat belajar matematika terjadi saat kegiatan belajar dan mengajar di sekolah maupun di berbagai tempat lain terjadi, serta sesudah belajar matematika dilakukan saat seorang siswa mengulang atau membahas kembali materi belajar matematika yang diberikan oleh guru tadi di sekolah. Bersama dengan orang tua, teman sekelas, maupun bersama yang lainnya.

Prestasi belajar matematika siswa Indonesia masih bisa dikategorikan rendah atau sangat rendah sekali. Hal tersebut dapat kita lihat dari hasil survei Trend in International Mathematics and Science Study (TIMSS) dan Program for International Student Assessment (PISA) yang masih menempatkan siswa Indonesia dalam zona bawah (Richardo, 2016:118). Ini dapat kita lihat dimana pada TIMSS, peringkat Indonesia pada tahun 2007 adalah 36 dari 49 negara, pada tahun 2011 peringkat Indonesia 38 dari 45 negara, dan pada tahun 2015 peringkat Indonesia adalah 45 dari 50 negara (Martyanti dan Suhartini, 2018:36). 


\section{Range: Jurnal Pendidikan Matematika Vol. 3 No. 1 Tahun 2021 Try Gunawan Zebua}

Pada PISA (Salim dan Prajono, 2018:595), peringkat Indonesia adalah: Hasil studi PISA Indonesia menduduki hasil peringkat yang kurang membanggakan dibandingkan dengan negara-negara lain. Pada bidang matematika, pada tahun 2000 Indonesia peringkat 39 dari 41 negara yang berpartisipasi dengan skor siswa adalah 367, pencapaian tahun 2003 Indonesia peringkat 38 dari 40 negara dengan skor 361, pada tahun 2006 Indonesia menduduki peringkat 50 dari 57 negara dengan skor 391, pada tahun 2009 Indonesia menduduki peringkat 61 dari 65 negara dengan skor 371, pada tahun 2012 Indonesia peringkat 64 dari 65 negara dengan skor 375, pada tahun 2015 Indonesia peringkat 63 dari 70 negara dengan skor 386 (Gunardi, 2017:3).

Selain memiliki prestasi belajar matematika rendah dan sangat rendah, siswa juga dalam kegiatan belajar matematika dapat dikatakan tidak memiliki prestasi belajar matematika atau dengan kata lain prestasi belajar matematika tidak ada $(0 \%)$. Hal tersebut dapat kita lihat dari siswa yang saat kegiatan belajar dan mengajar matematika terjadi suka bermain-main, mengganggu teman, tidak fokus dalam kegiatan belajar matematika, tidak suka dengan guru matematika dan pelajaran matematika, dan lain-lain.

Hal tersebut juga dapat kita lihat dari hasil pengamatan dan wawancara yang dilakukan oleh Trygu dalam bukunya yang berjudul Studi Literatur Problem Based Learning untuk Masalah Motivasi bagi Siswa dalam Belajar Matematika, dimana Trygu (2020:21) mengatakan bahwa: Berdasarkan hasil pengamatan peneliti saat Program Pengalaman Lapangan Terpadu (PPLT) di SMP Negeri 1 Gunungsitoli Utara, didapatkan bahwa saat ujian maupun ulangan terkadang ada siswa yang menyontek, siswa kurang aktif dalam kegiatan pembelajaran di kelas dan terkadang ada siswa yang tidak mengumpulkan tugas saat diberikan. Sedangkan berdasarkan hasil wawancara menurut Trygu (2020:21-22) didapatkan bahwa: berdasarkan hasil wawancara dengan guru mata pelajaran, didapatkan bahwa siswa memiliki minat belajar yang rendah, siswa mengalami kesulitan dalam belajar matematika dan terkadang ada siswa yang tidak mengerjakan tugas yang diberikan oleh guru.

Dari hasil pengamatan dan wawancara yang telah dilakukan oleh Trygu, maka dapat kita simpulkan bahwa siswa tidak memiliki prestasi belajar matematika. Hal tersebut disebabkan karena siswa yang tidak mengerjakan tugas yang berarti siswa tidak tahu apa tugas yang diberikan oleh guru, sehingga prestasi belajar matematika tidak ada atau tidak ada capaian dari siswa tersebut pada tugas karena siswa tidak mengerjakan tugas. Hal tersebut karena prestasi belajar adalah capaian siswa dalam kegiatan belajar. Selain itu, dikatakan bahwa minat belajar siswa rendah. Salah satu faktor yang mempengaruhi prestasi belajar matematika adalah minat belajar matematika siswa, dimana jika siswa memiliki minat dalam kegiatan belajar matematika maka siswa akan memiliki prestasi belajar matematika yang baik. Dimana hal tersebut dikatakan oleh Trygu dalam bukunya yang berjudul Menggagas Konsep Minat Belajar Matematika, dimana Trygu (2021:82) mengatakan bahwa manfaat dari timbulnya minat belajar matematika siswa adalah mempengaruhi dan meningkatkan proses belajar matematika, hasil belajar matematika dan bahkan prestasi belajar matematika.

Selain prestasi belajar matematika, hasil belajar matematika siswa juga dapat dikategorikan rendah atau sangat rendah sekali. Hal tersebut dinyatakan oleh Shoimin (2018:16), dimana Shoimin mengatakan bahwa hasil-hasil pengajaran dan pembelajaran berbagai bidang disiplin ilmu terbukti selalu kurang memuaskan berbagai pihak yang berkepentingan. Pendapat Shoimin tersebut mengatakan "berbagai bidang disiplin ilmu", itu berarti bahwa termasuk hasil belajar matematika yang rendah atau kurang memuaskan berbagai pihak yang berkepentingan.

Prestasi belajar matematika dan hasil belajar matematika itu sama, dimana hasil belajar matematika siswa adalah prestasi atau capaian siswa dalam belajar matematika. Rendahnya prestasi belajar matematika dan hasil belajar matematika disebabkan oleh salah satu faktor yaitu motivasi belajar matematika. Motivasi berpengaruh terhadap prestasi belajar matematika siswa dinyatakan oleh Suprijono (2014:162) sebagaimana sama dengan yang dikutip oleh Siregar dan Nara (2014:51-51). Studi yang dilakukan Suciati (1990) menyimpulkan bahwa kontribusi motivasi sebesar 36\%, sedangkan McClelland menunjukkan bahwa motivasi berpretasi (achievement motivation) mempunyai kontribusi sampai $64 \%$ terhadap prestasi belajar." 


\section{Range: Jurnal Pendidikan Matematika Vol. 3 No. 1 Tahun 2021 Try Gunawan Zebua}

Motivasi berpengaruh terhadap hasil belajar siswa dimana dinyatakan oleh Sardiman, dimana Sardiman (2016:84) mengatakan bahwa: hasil belajar akan menjadi optimal, kalau ada motivasi. Hal tersebut senada dengan yang dikatakan oleh Hamzah dan Muhlisrarini (2014:149) yang menyatakan bahwa: apabila motivasi meningkat maka pada akhirnya secara langsung atau tidak langsung dapat meningkatkan hasil belajar. Dari pendapat Sardiman serta Hamzah dan Muhlisrarini maka dapat diambil kesimpulan bahwa motivasi tersebut berpengaruh dan dapat meningkatkan hasil belajar dari siswa. Sehingga motivasi belajar matematika siswa dapat berpengaruh atau meningkatkan hasil belajar matematika siswa.

Dari beberapa pendapat di atas, maka dapat disimpulkan bahwa motivasi itu sangat penting untuk dimiliki karena berpengaruh dan meningkatkan prestasi atau hasil belajar siswa, sehingga motivasi itu sangat penting atau berguna sekali untuk semua orang tanpa terkecuali. Teori motivasi itu ada beberapa jenis, namun pada penelitian ini hanya diambil salah satu saja Teori Motivasi, yaitu: Teori Motivasi Abraham H. Maslow atau Teori Hierarki Kebutuhan Maslow.

Teori Motivasi Abraham Maslow sangat kita perlukan dalam kegiatan atau aktivitas belajar matematika. Hal tersebut karena Teori Motivasi Abraham Maslow dapat meningkatkan, berpengaruh atau mengoptimalkan proses belajar matematika, hasil belajar matematika dan prestasi belajar matematika, sehingga sangat penting untuk mengimplikasikan Teori Motivasi Abraham Maslow dalam kegiatan belajar matematika. Misalnya Teori Motivasi Abraham Maslow yang pertama, yaitu: Kebutuhan Fisiologis. Kebutuhan Fisiologis adalah kebutuhan akan fisik atau fisiologis seseorang seperti makanan dan minuman.

Jika sebelum belajar matematika seorang siswa belum sarapan atau makan di pagi hari, maka dapat membuat siswa terserang penyakit tertentu atau dapat membuat perut siswa berbunyi terus sehingga siswa tersebut tidak akan lagi fokus dalam kegiatan belajar matematika. Namun, jika siswa sudah sarapan atau makan di pagi hari, maka siswa akan fokus dalam kegiatan belajar matematika. Siswa yang fokus akan mengakibatkan proses belajar baik, sehingga hasil dan prestasi belajar matematika tersebut menjadi ikut baik pula. Itu menyebabkan Teori Motivasi Abraham Maslow tersebut sangat diperlukan sekali. Tujuan Penelitian adalah: untuk meneliti bagaimana Implikasi Teori Motivasi Abraham H. Maslow dalam Belajar Matematika siswa. Kegunaan penelitian adalah untuk mengetahui bagaimana cara Implikasi Teori Motivasi Abraham H. Maslow dalam Belajar Matematika siswa.

\section{Metode Penelitian}

Penelitian ini dilakukan dengan menggunakan metode penelitian Studi Literatur. Studi Literatur adalah Metode Penelitian yang dilakukan melalui bahan Pustaka seperti buku maupun jurnal tertentu yang sesuai dengan masalah penelitian yang diangkat (Trygu, 2020:28). Pada penelitian ini menggunakan buku asli tulisan Abraham H. Maslow yang berjudul Motivation and Personality (terjemahan Achmad Fawaid dan Maufur, penerbit Cantrik Pustaka), kemudian peneliti menganalisis dampak Teori tersebut jika diimplikasikan dalam kegiatan belajar matematika terhadap hasil belajar matematika siswa. Teknik analisis dilakukan dengan menggunakan analisis isi (Content Analysis). Dimana menurut Eriyanto (2013:47) Analisis Isi adalah menggambarkan suatu pesan dari tulisan yang ada atau dari tulisan yang diteliti.

\section{Hasil Penelitian dan Pembahasan}




\section{Range: Jurnal Pendidikan Matematika Vol. 3 No. 1 Tahun 2021 Try Gunawan Zebua}

Teori Motivasi Abraham Maslow sangat kita perlukan dalam kegiatan atau aktivitas belajar matematika. Hal tersebut karena Teori Motivasi Abraham H. Maslow dapat mempengaruhi atau meningkatkan Hasil Belajar Matematika siswa. Sehingga sangat penting untuk mengimplikasikan Teori Motivasi Abraham Maslow dalam kegiatan belajar matematika. Teori Motivasi Abraham Maslow dan implikasinya dalam belajar matematika, yaitu:

\section{A. Kebutuhan Fisiologis}

Kebutuhan Fisiologis adalah kebutuhan awal atau dasar dalam Teori Hirarki Kebutuhan Abraham H. Maslow. Kebutuhan fisiologis adalah kebutuhan yang berdasarkan pada fisik (tubuh) seseorang. Misalnya makanan supaya tidak lapar lagi, sedangkan minuman untuk membuat tidak haus lagi.

Pada kebutuhan fisiologis ini dalam belajar matematika, seorang guru maupun para siswa harus terlebih dahulu memenuhi kebutuhan fisiologis sebelum belajar matematika. Kebutuhan fisiologis tersebut terkait dengan makanan, minuman, pakaian, dan lain-lain sebagainya. Misalnya tentang makan dan minum, seorang siswa yang tidak terpenuhi akan kebutuhan makan dan minum akan mengalami penyakit sakit perut atau kehausan, sehingga siswa tidak fokus dalam kegiatan belajar matematika. Dari hal tersebut maka dipandang perlu bagi seorang guru maupun para siswa untuk memenuhi kebutuhan fisiologisnya masing-masing sebelum proses belajar dan mengajar terjadi, yaitu kebutuhan akan makanan dan minuman. Jika siswa pada awalnya belum sempat sarapan karena terlambat bangun, maupun alasan yang lainnya, alangkah lebih baiknya jika seorang guru memberikan izin terlebih dahulu kepada siswa tersebut untuk sarapan atau makan pagi.

Begitu juga bagi yang tidak sempat minum, guru dapat memberikan kesempatan kepada siswa untuk minum dalam kelas. Namun siswa yang diberikan izin perlu diawasi, dimana bisa jadi siswa menyalahgunakannya dengan hal-hal yang lain. Misalnya siswa makan dan minum dalam waktu yang lama, dimana siswa tersebut membuat lama agar waktu pembelajaran dapat berakhir tanpa siswa rasakan atau tanpa siswa tersebut ikut serta dalam proses pembelajaran. Selain itu, siswa dapat juga beralasan bahwa makanan dan minumannya ada disana atau disitu, dengan kata lain ditempat lain sehingga kehabisan waktu yang banyak dalam memperolehnya. Untuk menghindari hal tersebut terjadi, sekolah bisa memberikan kepada siswa makanan atau minuman dengan harga yang murah atau malah gratis (tidak dipungut biaya sama sekali).

Selain makan dan minum, ada juga kebutuhan siswa akan toilet (buang air kecil). Toilet di dalam suatu sekolah terkadang jumlahnya tidak sesuai dengan jumlah siswa yang membuang air kecil, sehingga ada siswa yang terkadang menahan kencingnya karena toiletnya penuh, atau malah kencing di sekitar bangunan sekolah selain toilet. Hal tersebut dapat menimbulkan aroma yang tidak sedap saat pembelajaran di sekolah terjadi. Toilet yang kurang bersih tersebut juga dapat membuat orang-orang yang berkunjung di sekolah tidak nyaman dengan aroma yang ada. Pakaian juga merupakan kebutuhan dari fisik seorang siswa. Terkadang dalam proses pembelajaran, siswa menggunakan baju yang itu-itu saja atau bahkan tidak menggunakan seragam sekolah karena siswa tersebut maupun orangtua tidak sanggup untuk membeli seragam sekolah (baju sekolah). Apalagi sekolah-sekolah di daerah pelosok yang serba kesusahan ini dan itu. Pemerintah pada masa kini memberikan bantuan dana kepada siswa untuk membeli seragam sekolah bagi yang tidak mampu. Namun, terkadang juga ada orangtua yang menyalahgunakan bantuan uang seragam sekolah untuk membeli sejumlah kebutuhan pokok seperti beras, mie instan maupun telur, dan lain-lain. Ada yang begitu uang cair langsung membeli seragam dan lalu membeli yang lain, tetapi ada juga yang membeli kebutuhan yang lain baru membeli seragam sekolah. Dari hal tersebut, pihak sekolah dapat menjelaskan kembali maksud atau tujuan dari pemerintah memberikan bantuan. Selain itu, pihak sekolah juga dapat memberikan sangsi bagi yang melanggar berupa pengalihan bantuan kepada pihak lain yang lebih baik lagi.

Selain itu, kebutuhan fisik dari seorang siswa adalah olahraga. Olahraga dapat membuat fisik atau tubuh dari seorang siswa menjadi lebih sehat, sehingga siswa semakin sehat atau semakin mudah menyerap pengetahuan dari guru. Siswa juga menjadi tidak mengantuk atau menguap saat proses pembelajaran terjadi. Sehingga perlu bagi sekolah untuk mengadakan olahraga paling tidak 1 kali dalam 1 


\section{Range: Jurnal Pendidikan Matematika Vol. 3 No. 1 Tahun 2021 Try Gunawan Zebua}

minggu. Dalam proses pembelajaran juga siswa dapat diberikan kesempatan olahraga sejenak seperti memutar kepala secara perlahan-lahan sendiri ke kanan atau ke kiri, menggerakkan tangan secara bergantian ke kanan atau ke kiri, ke atas atau ke bawah, dan lain-lain. Hal tersebut dapat membuat siswa menjadi fokus atau konsentrasi dalam proses pembelajaran matematika yang dilakukan, sehingga dapat mempengaruhi atau meningkatkan Hasil Belajar Matematika siswa. Begitu juga dengan kebutuhan fisik yang lainnya dalam kegiatan belajar matematika.

\section{B. Kebutuhan Rasa Aman}

Kebutuhan rasa aman adalah kebutuhan pada tahap kedua Teori Hirarki Kebutuhan Abraham H. Maslow. Menurut Maslow (2018:73) dalam bukunya, kebutuhan akan rasa aman itu adalah: keamanan, stabilitas, ketergantungan, perlindungan; kebebasan dari rasa takut, cemas dan kekacauan; kebutuhan akan struktur, ketertiban, hukum, dan batasan; kekuatan pelindung dan lain sebagainya. Dari pendapat Maslow tersebut di atas, maka dapat diambil kesimpulan bahwa kebutuhan rasa aman adalah kebutuhan akan keamanan, stabilitas, ketergantungan, dan lain-lain.

Pada kebutuhan rasa aman ini seorang guru maupun siswa membutuhkan yang namanya rasa aman, dari suatu ancaman tertentu, maupun dari suatu bahaya tertentu. Salah satunya saat terjadi bencana alam maupun maling yang mencuri di dalam kelas. Selain itu, rasa aman dalam proses pembelajaran matematika bisa dilakukan dari guru pembelajaran matematika, dimana terkadang guru begitu galak atau kejam dalam kegiatan belajar matematika. Salah sedikit dihukum, salah sedikit dicubit, salah sedikit dikatain, dan lain-lain sebagainya. Hal tersebut dapat membuat siswa merasa tidak aman, dimana siswa merasakan ketakutan atau kekuatiran, serta kecemasan yang luar biasa. Memang menghukum tersebut dapat membuat siswa jera, namun terkadang ada malah siswa yang suka dihukum karena siswa tersebut dapat dikenal oleh berbagai siswa di kelas lain yang melihat siswa tersebut saat dihukum.

Selain itu, seorang siswa dapat merasakan tidak aman saat siswa tersebut dibully atau dipermalukan oleh teman-temannya dalam 1 kelas, sehingga siswa merasa tidak aman dalam proses pembelajaran. Siswa tersebut dibully karena tubuhnya yang gendut, tingkah laku yang lemah gemulai, dan lain-lain. Seorang guru harus menjadi teman atau sahabat kepada siswa, dimana seorang guru harus menghentikan tindakan bully tersebut karena merupakan salah satu tindakan yang berbahaya atau dilarang. Itu dapat membuat siswa menjadi gila atau tertekan. Siswa menjadi malas datang ke sekolah, sehingga dapat membuat proses, hasil belajar, maupun prestasi belajar siswa menjadi rendah atau malah sangat rendah sekali.

Di dunia ini tidak ada makhluk yang sempurna, bahkan hewan pun masing-masing ada kelebihan maupun kekurangannya. Ada hewan yang hanya tahu memanjat pohon, namun saat disuruh berenang malah tidak berani sama sekali bersentuhan dengan air. Begitu juga, ada hewan yang berenang terampil sekali, namun saat disuruh memanjat pohon malah tidak bisa melakukannya. Perbedaan atau kekurangan itu ada bukan untuk dijadikan bahan penghinaan atau pengolok-olok, melainkan menjadi ajang pelengkap untuk mencapai kesempurnaan yang luar biasa. Begitu juga dengan kebutuhan yang lain atau dan lainlain.

\section{Kebutuhan Sosial}

Kebutuhan Sosial adalah tahap ketiga dari Teori Hirarki Kebutuhan Maslow. Menurut Maslow (2018:76) kebutuhan sosial adalah kebutuhan akan cinta, kasih sayang dan rasa dimiliki. Dari pendapat Maslow di atas ada 3 pengertian dari Kebutuhan Sosial, yaitu: kebutuhan akan cinta, kasih sayang dan rasa dimiliki. Kebutuhan Sosial ini dalam kegiatan belajar matematika harus dimiliki oleh seorang guru maupun para siswa dalam proses pembelajaran yang terjadi, dimana pada kebutuhan ini seseorang merasa butuh akan hubungan atau interaksi dengan sesama siswa, maupun siswa dengan guru, kebutuhan akan dicintai oleh guru dan teman-temanya dalam kelas, dan lain-lain sebagainya. Pada kebutuhan jenis kebutuhan sosial ini dalam belajar matematika, harus dilakukan dimana seorang guru harus memberikan perhatian atau empati kepada siswa dalam proses belajar dan mengajar terjadi. 


\section{Range: Jurnal Pendidikan Matematika Vol. 3 No. 1 Tahun 2021 Try Gunawan Zebua}

Selain itu, seorang guru harus memberikan atau mewujudkan keadilan bagi seluruh siswa. Guru jangan hanya menghukum si "A" saja, tetapi si "B", si "C", atau yang lainnya malah tidak dihukum sama sekali karena salah dalam menjawab soal saat belajar matematika. Itu merupakan salah satu wujud ketidakadilan yang dilakukan oleh guru. Itu tidak perlu dilakukan karena dapat membuat kecemburuan yang terjadi kepada siswa yang lainnya. Itu dapat mengakibatkan perkelahian, permusuhan atau pertikaian.

Guru juga harus bisa memahami potensi yang dimiliki oleh siswa, jangan hanya mengajar atau terus mengajar saja tanpa mengetahui apa kelebihan atau potensi yang dimiliki oleh siswa tersebut. Hal tersebut karena setiap orang memiliki kelebihan atau potensi, dan berbagai faktor sosial yang lain atau dan lain-lain.

\section{Kebutuhan akan Harga Diri atau Pengakuan}

Kebutuhan Penghargaan adalah tahap keempat dari Teori Hirarki Kebutuhan Maslow. Menurut Maslow (2018:77) tahap keempat ini adalah tahap dimana kebutuhan atau keinginan akan evaluasi yang stabil dan tegas akan diri mereka sendiri, harga diri dan penghargaan diri, dan pengakuan orang lain. Dari pendapat Maslow di atas, maka dapat diambil kesimpulan bahwa kebutuhan untuk harga diri atau pengakuan adalah penghargaan diri, serta pengakuan dari orang lain.

Kebutuhan Penghargaan dalam kegiatan belajar matematika terjadi dimana guru menghormati siswa, begitu juga dengan siswa yang menghormati guru selama proses belajar matematika terjadi. Selain itu, ada juga rasa saling menghargai antara guru dengan siswanya. Harga diri siswa bisa dikembangkan dengan mengembangkan apa pengetahuan baru berdasarkan dari latar pengetahuan yang dimiliki oleh siswa, dimana terkadang sebelum proses pembelajaran terjadi ada yang telah diketahui oleh siswa sebelumnya. Itu perlu dikembangkan lagi, dimana dapat membuat siswa percaya diri atau harga dirinya meningkat.

Saat menghukum atau mendisiplinkan siswa, jangan dilakukan didepan umum atau didepan banyak siswa. Hal tersebut dapat membuat siswa menjadi malu atau tertekan. Apalagi jika diungkitungkit masa lalu atau masalah yang memalukan yang dilakukan oleh siswa pada saat itu, apalagi yang dilakukan sebelumnya. Selain itu, dalam pengambilan keputusan dapat melibatkan para siswa dalam pengambilan keputusan yang terkait dengan kepentingan para siswa itu sendiri. Selain itu, bisa dilakukan dengan cara memberikan atau meletakkan karya-karya siswa didinding atau di majalah dinding sekolah, sehingga dapat meningkatkan harga diri siswa, atau yang sebagainya.

\section{E. Kebutuhan Aktualisasi Diri}

Kebutuhan Aktualisasi Diri adalah kebutuhan pada tahap terakhir atau tahap yang berada paling atas pada gambar Teori Hirarki Kebutuhan Maslow. Menurut Maslow (2018:79) kebutuhan aktualisasi diri adalah keinginan orang akan kepuasan diri, yaitu kecenderungan mereka untuk mengaktualisasikan potensi diri mereka. Lebih lanjut Maslow (2018:79) mengatakan bahwa: kecenderungan ini bisa diungkapkan sebagai keinginan untuk semakin menjadi diri sendiri, untuk menjadi apa yang orang mampu. Dari pendapat Maslow di atas, maka dapat diambil kesimpulan bahwa kebutuhan aktualisasi diri adalah kebutuhan akan menjadi diri sendiri, untuk menjadi apa yang orang mampu, berpendapat, dan memberikan penilaian serta kritik terhadap sesuatu.

Tahap terakhir pada Teori Motivasi Maslow adalah kebutuhan akan aktualisasi diri, dimana seorang guru maupun siswa dalam kegiatan belajar matematika butuh untuk berpendapat akan hasil diskusi kelompok lain dalam kegiatan belajar matematika, kebutuhan siswa untuk mengemukakan ide, serta memberikan penilaian dan kritik terhadap hasil pembahasan kelompok lain maupun hasil belajar siswa dalam kegiatan belajar matematika.

Selain itu, pembelajaran dilakukan dengan model pembelajaran yang mengaitkan masalah atau halhal dalam belajar matematika dengan kehidupan sehari-hari. Model Pembelajaran yang mengaitkan dengan masalah sehari-hari itu adalah Model Pembelajaran Problem Based Learning, Model 


\section{Range: Jurnal Pendidikan Matematika Vol. 3 No. 1 Tahun 2021 Try Gunawan Zebua}

Pembelajaran Contextual Teaching and Learning, dan berbagai model pembelajaran yang lain, sehingga siswa dapat mengerti manfaat dari apa yang dipelajari dalam setiap pertemuan atau pembelajaran.

Selain itu, seorang guru bisa memberikan kesempatan kepada siswa untuk melakukan sesuatu yang terbaik. Dengan kata lain memberikan kesempatan kepada siswa untuk melakukan yang terbaik, jangan hanya pilih siswa yang itu-itu saja yang dianggap sudah mampu atau mahir, melainkan juga siswa yang lain yang biasa-biasa saja, atau dan lain-lain.

Teori Motivasi Abraham H. Maslow ini sangat perlu atau berguna sekali, dimana mengingat bahwa hasil belajar matematika siswa di sekolah masih bisa dikategorikan rendah. Hal itu diakibatkan karena Teori Motivasi Abraham H. Maslow dapat mempengaruhi atau meningkatkan Hasil Belajar Matematika siswa.

\section{Kesimpulan}

Simpulan

Teori Motivasi Abraham H. Maslow pada tahap pertama dapat diterapkan dalam kegiatan belajar matematika dengan cara memberikan makanan dan minuman kepada siswa, tahap kedua dapat diterapkan dengan cara membuat siswa aman dalam kegiatan belajar matematika, tahap ketiga dapat diterapkan dengan menjalin komunikasi antara guru dan siswa, tahap keempat dapat diterapkan dengan cara adanya saling menghargai antara guru dengan siswa maupun sesama siswa, dan tahap kelima dapat diterapkan dengan cara memberikan kesempatan kepada siswa untuk mengemukakan pendapat dalam kegiatan diskusi. Penerapan Teori Motivasi Abraham H. Maslow dapat mempengaruhi atau meningkatkan Hasil Belajar Matematika siswa. Siswa akan menjadi fokus atau konsentrasi saat belajar matematika di dalam kelas.

Saran

Adapun yang menjadi saran bagi penelitian berikutnya adalah jika ada masalah rendahnya hasil belajar matematika dapat digunakan atau diimplikasikan Teori Motivasi Abraham H. Maslow.

\section{Daftar Pustaka}

Amalia, A. (2020). Aplikasi Teori Kebutuhan Maslow dalam Pembelajaran Bahasa Arab (Implementasi Pendekatan Humanistik). Edulab: Majalah Ilmiah Laboratorium Pendidikan, 4(2). https://doi.org/10.14421/edulab.2019.42-02

Eriyanto. (2011). Analisis Isi: Pengantar Metodelogi untuk Penelitian Ilmu Komunikasi dan IlmuIlmu Sosial Lainnya. Jakarta: Kencana.

Gunardi, E. (2017). Analisis Kemampuan Literasi Matematis Siswa Kelas VIII A SMP Pangudi Luhur Moyudan Tahun Ajaran 2016/2017. Skripsi. Yogyakarta: Program Studi Pendidikan Matematika, Jurusan Pendidikan Matematika dan Ilmu Pengetahuan Alam, Fakultas Keguruan dan Ilmu Pendidikan, Universitas Sanata Dharma.

Hamzah, A. dan Muhlisrarini. (2014). Perencanaan dan Strategi Pembelajaran Matematika. Jakarta: PT RajaGrafindo Persada.

Marsigit. (2013). Pendidikan Karakter Melalui Pembelajaran Matematika. (Online), (https://www.academia.edu/3427369/Pidato_Pengukuhan_Guru_Besar_a_n_Marsigit_18_April_2 $013)$.

Martyanti, A. dan Suhartini. (2018). Etnomatematika : Menumbuhkan Kemampuan Berpikir Kritis Melalui Budaya dan Matematika. Indomath: Indonesia Mathematics Education, 1(1). https://doi.org/10.30738/indomath.v1i1.2212 


\section{Range: Jurnal Pendidikan Matematika Vol. 3 No. 1 Tahun 2021 Try Gunawan Zebua}

Maslow, A. H. (2018). Motivation and Personality. Diterjemahkan oleh Achmad Fawaid dan Maufur. 2018. Yogyakarta: Cantrik Pustaka.

Richardo, R. (2016). Peran Ethnomatematika dalam Penerapan Pembelajaran Matematika pada Kurikulum 2013. Literasi: Jurnal Ilmu Pendidikan, 7(2). https://doi.org/ 10.21927/literasi.2016.7(2).118-125.

Salim, dan Prajono, R. (2018). Profil Kemampuan Literasi Matematis Siswa Kelas VIII1 SMP Negeri 9 Kendari. Indonesian Digital Journal of Mathematics and Education, 5(9).

Sardiman, A. M.. (2016). Interaksi dan Motivasi Belajar. Jakarta: Rajawali Pers.

Shoimin, A. (2018). 68 Model Pembelajaran Inovatif dalam Kurikulum 2013. Yogyakarta: Ar-Ruzz Media.

Siregar, E. dan Nara, H. (2014). Teori Belajar dan Pembelajaran. Bogor: Penerbit Ghalia Indonesia.

Suprijono, A. (2014). Cooperative Learning. Yogyakarta: Pustaka Pelajar.

Trygu. (2020). Studi Literatur Problem Based Learning untuk Masalah Motivasi bagi Siswa dalam Belajar Matematika. The First On-Publisher in Indonesia: Guepedia.

Trygu. (2021). Menggagas Konsep Minat Belajar Matematika. The First On-Publisher in Indonesia: Guepedia. 